\author{
Катарина Митровић \\ Центар за историјску географију и историјску демографију \\ Филозофски факултет Београд \\ Међународни центар за православне студије, Ниш \\ e-mail:katmit035@gmail.com
}

\title{
КРАЉИЦА ЈЕЛЕНА И СИНАЈСКА ГОРА
}

Апстракт: Тихомир Р. Ђорђевић је на једном предавању одржаном на Универзитету у Београду 1925. године истакао да је краљииа Јелена са својим синовима, краљевима Драгутином и Милутином, богато обдарила Богородичин манастир на Синају. У раду се разматрају подаци о епистоларном пријатељству, које је краљииа Јелена годинама одржавала с православним духовницима у Јерусалиму, на Светој Гори и Синају, у Раиту, саопштени у њеном Житију из пера архиепископа Данила Другог. То су за сада једине иоле поуздане вести о односима ове српске владарке и Синајске Горе.

Кључне речи: Краљица Јелена, архиепископ Данило Други, Синајска Гора, епистоларно пријатељство, дарови

Краљица Јелена, супруга краља Уроша I (1243-1276), једна је од личности које су својим ликом и делом привлачиле велику пажњу како савременика тако и потоњих проучавалаца српске средњовековне историје, укључујући модерну историографију. Остала је упамћена као мајка краљева Драгутина и Милутина, способна владарка која је управљала поседом типа држава као први силни у Српској држави, ктиторка Манастира Градац и неколико бенедиктинских и фрањевачких цркава у Поморју и покровитељка образовања женске деце, за коју је основала посебну школу при своме двору у Брњацима. ${ }^{1}$ Краљица Јелена је и прва жена у српској историји којој је посвећено житије. Архиепископ Данило Други представио је женски лик који је одликовала блага и побожна нарав, али и заповедни тон у обраћању, склоност ка добротворном раду и милосрђу у складу са Христовим заповестима и јеванђеоским примерима, широкогрудо прихватање оних који су се налазили на друштвеним маргинама због ниског порекла, болести, сиромаштва, напуштености или неуклопљености у устаљени поредак, спремност да се ближњи саслуша и да му се помогне саветом, али и велика ученост као плод познања свих књига. ${ }^{2}$ Други извори, пре свега дипломатичка грађа, показују да је краљица Јелена била веома вешта и када је реч о сложеним дипломатским играма, у првом реду односима са Апостолском столицом у доба настојања да се Лионска унија из 1274. године спроведе у дело. ${ }^{3}$ Краљичино порекло сумирано епитетом Анжујска, који јој се деценијама

1 О личности, животу и владавини краљице Јелене види: Томин 2014. (с прегледом литературе). О њеној држави види: Копривица 2015, 13-26.

2 ЖКЈ 2017. Овом приликом коришћено је најновије издање Житија у преводу на савремени српски језик, које је приредио Д. Дојчиновић.

3 Поповић 2010, 80-86 с прегледом литературе. 
неосновано додаје, такође је изазивало бројне полемике у науци. Данас је с великим степеном вероватноће утврђено да је она кћи Јована Анђела, војводе Срема, сина византијског цара Исака II Анђела (1185-1195) и угарске принцезе Маргарете, кћери краља Беле III. ${ }^{4}$ Мајка краљице Јелене била је Матилда грофица Пожеге, по женској линији директна потомкиња Петра I де Куртенеа, сина француског краља Луја VI (11081137)..$^{5}$ Писмо-заклетва краљице Јелене упућено дубровачком архиепископу Алеарду, кнезу Ивану Сторлату и општини изазвало је бројне полемике у научним круговима због извесне сенке коју баца на краљичин лик. ${ }^{6}$ Такође, питања која се односе на вероисповест краљице Јелене и даље заокупљају велику пажњу, према нашем суду потпуно непримерену, будући да се углавном ради о пројектовању модерних погледа на средњовековне обичаје и прилике. ${ }^{7}$ Напослетку, Јелена је једина српска средњовековна света краљица, која има званично установљен и признат култ. ${ }^{8}$

Краљица Јелена је остала упамћена и по томе што је одржавала епистоларно пријатељство с већим бројем духовника из разних делова православне васељене, о чему смо обавештени захваљујући њеном животописцу Данилу Другом. ${ }^{9}$ На ову занимљиву појединост из краљичиног живота пре једног века указао је Тихомир Р. Ђорђевић у јавном предавању под називом Српске светиње у Палестини, које је на позив Материнског удружења одржао 18. фебруара 1925. године на Београдском универзитету. Непосредан повод за одабир теме предавања била је мисија јерусалимског патријарха, која је мало пре тога посетила Београд, по свој прилици последњих дана јануара 1925. године. ${ }^{10}$ Осврнувши се на чињеницу да је српских монаха било не само у Манастиру Светих арханђела Михаила и Гаврила у Јерусалиму, задужбини краља Милутина, већ и у другим деловима Палестине, Тихомир Р. Ђорђевић истиче да је Манастир Свете Богородице у Синају посетио још Свети Сава, те да га је краљица Јелена са својим синовима Драгутином и Милутином богато обдарила. У истом манастиру крајем XIV века игуман је био Србин Јоаникије. Посредством извесних путника до аутора су стигли гласови да је на Синају, али и у Раиту и Манастиру Светог Саве Освећеног, било доста старих српских књига, о којима се није водило довољно бриге. Ђорђевић наводи и податак да је Јаков, митрополит Сера, Богородичином манастиру на Синају 1360. године даривао четири књиге: Часловаи, Припеснаи, Псалтир и Пјеније Златоустово с молбом српским и грчким монасима да дароване књиге не износе из манастира. ${ }^{11}$

О односима краљице Јелене с православним оцима у светом граду Јерусалиму, на Синају и Раиту и у Светој Гори Атонској у овом тренутку познато је само оно што је о тој теми забележио архиепископ Данило Други. Недуго након смрти краља Уроша I, која се догодила 1. маја по свој прилици 1277. године у туробним околностима владарског и родитељског пораза, обудовела краљица тешко се разболела. За борбу с душевним и

4 McDaniel 1982-1983, 43-50.

5 Мајка грофице Матилде и претпостављена бака краљице Јелене била је Маргарета од Вијандена, унука Петра I де Куртенеа и праунука краља Луја VI. Маргаретин отац био је латински цар Петар II де Куртене (1216-1217). Њен брат Балдуин II такође је био латински цар у периоду 1228-1261, Узелац 2021, 187-206.

6 Поповић 2015, 53-60.

7 Види одличан осврт на ову проблематику: Јовић 2015, 171-182.

8 Тодић 2018, 33-50.

9 Видети нове радове који се баве структуром, темама, мотивима, поетиком и другим књижевним особинама Житија краљиие Јелене: Јухас Георгиевска 2013, 27-40; Бојовић 2015, 139-146; Дојчиновић 2015, 151-166.

10 Ђорђевић $1925,3$.

11 Исто, 9-10. 
телесним искушењима на располагању је имала духовна средства - покајање, пост и милостињу, који на тај начин постају централне теме око којих владика Данило развија приповедање о својој јунакињи. ${ }^{12}$ Он ју је не само добро познавао већ је дуго времена с њом одржавао и пријатељске везе. Властите патње подстакле су краљицу да се посвети бризи о потребитима због чега је, по речима животописца, љубила ниште, давала милостињу, одевала наге и у свој дом примала бескућнике. ${ }^{13}$ Јелена се налази у средишту манифестације божанске љубави. Њено човекољубље испољава се кроз чињење милостиње, у основи свих њених поступака лежи љубав, што владика Данило посебно наглашава. ${ }^{14}$ Доброчинства су краљицу подстицала да се сећа својих грехова од младости, те је тако документарни слој који доноси конкретне податке о њеној преписци с православним духовницима, убачен у трећу тематску целину у знаку подвига милостиње ${ }^{15}$ Краљица је грехе исповедала у писмима упућиваним у Јерусалим, на Свету Гору, у монашку заједницу Раит на обали Суецког залива и у Манастир Свете Катарине на Синају. Писма је слала по својим људима, часним и достоверним и великоименитим монасима до краја живота. Владика Данило у једном пасусу доноси сумаран садржај њених писама:

Господо моја и оци, сетите се да сте ви силни у имену Господњем, и зато сте дужни да носите наше немоћи. Јер ево ми који смо у сујети овога сујетнога света, ако и хоћемо да духом живимо, колико је угодно Господу, то не можемо да постигнемо. Јер сав овај свет лежи у злу (Прва посланица Јованова 5, 19), као што рече божанствена реч. Јер ако се душа не остави светских брига, то не може ни Бога истинито волети, ни ђавола достојно мрзети. Пошто је наш ум обузет метежсом животних похота, као што се лађа на морској пучини љуља од морских таласа, тако и ја грешна љуто тонем у гресима мојима. Но молите Господа за мене недостојну, не бих ли како Богу угодним вашим молитвама постала достојна да примим такав дар од Христа да доспем у богоугодна мecma. ${ }^{16}$

Краљица је заједно са писмима на духовна одредишта слала и многе дарове. Доброразумни оци су на њена писма и обилата даривања одговарали поукама у облику заповести којих се она верно придржавала с љубављу и захвалношћу. Суштину порука које су блажени оци упућивали краљици Јелени владика Данило сажео је у једном одељку:

Богољубиво чедо наме, поверено нам у Господу, ево примивши кротке и богоразумне речи твојих писама, насладисмо се. Ако хоћеш, можеш земаљским иарством искупити небесно, и узићи ка небесноме цару веселим ногама. Знаш град наш, у коме ћемо живети. Зашто да у туђем спремамо села и здања и сујетне станове? Ако ове спремамо у овом веку, то је у туђем граду познато, $и$ нека никако не чека да се врати у свој, тј. у вишњи Јерусалим. Достојно ти је, христољубива, да се сетиш речи апостола Павла, који каже: „Наш је живот на небесима, оданде чекамо нашег Спаситеља Христа" (Посланица Филипљанима

12 Јухас Георгиевска 2013, 30-31.

13 ЖКЈ 2017, 17-18.

14 Бојовић 2015, 142, 144.

15 Јухас Георгиевска 2013, 32.

16 ЖКЈ 2017, 19-20. 
3, 20, 31). И опет: „Бивајте слични Богу, и као чеда вазљубљена ходите у љубави, као што и Христос заволи вас, јер се нарекосте синови Вишњега” (Видети Јеванђеље по Луки 6, 35; Посланица Филипљанима 4, 1). Постиди се у садашњем веку онога који те је тако заволео, да се не постидиш у доласку његова јављања. Служи му са страхом као владици по природи. Радуј му се са трепетом као изару по благодати. Сила је царство небесно и они који се са силом труде у њега чистим срцима са смелошћу, такови га грабе (Видети Јеванђеље по Матеју 11, 12). Венаи победе, исплетен од руке Сведржитеља, дарује се онима који су претрпели зло, као добрим војницима Христа Бога, који су примили беде и скрби и напасти, који су заборавили природу и презрели смрт, да стекну ияарство небесно. Не постизава се царство небесно ни речима, ни лепотом ни родом, ни јачином, ни годинама, ни силом вере. Ове речи, које ти шаљемо христољубива, ако сачуват и примиш у свој ум љубављу истините вере срца твога, а уз то не одлучуј се љубави према странцима, не одступи од истине, гони мир и правду са свима који призивају име Господње. Све ово што си чула сачувај, и неће наићи на тебе искушење лукавога. Ако и наиђе, не похули но благодари Господа говорећи: „За све што ме је снашло нека буде благословено име Господње на векове (Књига о Јову 1,21$)$ ". Не дај безумља уснама својима Господу. ${ }^{17}$

Опонашајући на известан начин псалмопојца Давида чијим су устима слатке речи оваквих поука биле више од меда, краљица Јелена, премда непрекидно искушавана, постави себе пред Господом, као непостидна раденика, трудећи се да пређе из ропства у слободу и наследи добру земљу, коју је обећао Господ онима који га љубе. Владика Данило не наводи тачно дарове које је краљица слала на Синај и у друге православне светиње, али се то може закључити на основу даљег излагања. Поступајући у складу са препорукама и заповестима блажених отаща синајских, јерусалимских, раитских и атонских, краљица се усрдно молила и присуствовала свеноћним бдењима у складу с правилима појединих цркава и манастира. Непрекидно је чинила милостињу светињама дарујући им свете сасуде израђене од залата и сребра и украшене бисерима и драгим камењем и одежде за јереје, а пружала је и све друго што је на потребу. Посебно је занимљив један исказ: стављајући божаствене књиге у своме дому ${ }^{18}$, који као да наводи на закључак да је негде у краљичиној близини, можда баш у њеном дому, на двору у Брњацима или у некој од резиденција на подручју њене државе у којима је повремено боравила, постојао скрипторијум у коме су преписиване и украшаване књиге које су потом као скупоцени дарови одашиљане црквама и манастирима. Поред тога што се дописивала са блаженим оцима из Свете земље, Египта и Атоса, краљица је имала и свог личног духовника с којим је одржавала пријатељске везе. Реч је о рашком епископу Павлу који ју је пред смрт исповедио и причестио. ${ }^{19}$

Осим старања о црквама и монашким обитељима, краљичино човекољубље изражавало се и кроз непрестану бригу за удовице и сироте и ниште и све који требају, а којима је богатство земаљског иарства свога нештедемице раздавала. Врхунац њеног човекољубља представља оснивање школе за кћери сиротих родитеља које је сабирала у целој својој области. ${ }^{20}$ После тога владика Данило прелази на следећу тему посветивши

17 Исто, 20-21.

18 Исто, 22.

19 Исто, 41.

20 Исто, 23. Недавно је проф. др Бранислав Тодић убедљиво показао да се податак о краљичиној школи за девојке налази једино у најмлађем препису њеног Житија из 1780. године, БСП, Рс 51. 
пажњу краљичином братољубљу и њеној бризи за синове краљеве - Драгутина и Милутина. ${ }^{21}$

Занимљиво је да и кратко пролошко житије, писано по узору на опширно житије из пера владике Данила Другог, помиње везе које је краљица Јелена одржавала са Јерусалимом и Синајем, а које су биле вишеструко утврђене њеним даровима. Писац кратког прошлог житија био је, по свој прилици, рашки митрополит Висарион који се на том положају налазио око 1600. године. Митрополит Висарион је вероватно написао и тропаре и кондаке намењене литургијском прослављању краљице Јелене. ${ }^{22}$ Настојањем овог књигољубивог јереја, као и старца Пајсија и јеромонаха Стефана, игумана Ђурђевих ступова, живот у Манастиру Градац био је обновљен пред крај XVI и с почетка XVII века. $^{23}$

Краљица Јелена је водила преписку и са папама Николом IV и Бенедиктом XI, могуће и са још неким црквеним достојанственицима и ученим богословима у свету латинског хришћанства. ${ }^{24}$ Папа Никола IV је у писму од 15. марта 1291. године допустио Helenae reginae Servie да за свог исповедника (confessor) изабере Николу из Вошице (Nicolaus de Vosica). ${ }^{25}$ Краљица Јелена је даривала и римокатоличке цркве и манастире. Познато је да је заједно са Драгутином и Милутином Цркви Светог Николе у Барију поклонила икону која је приказивала овог светитеља, а која данас није сачувана. У Ватикану се чува икона Светих апостола Петра и Павла, дар краљице Јелене и њених синова Апостолској столици. ${ }^{26}$ Владика Данило Други не говори о везама краљице Јелене са светом западног хришћанства, што је посве очекивано. Међутим, могуће је да су управо дарови мајке и синова намењени Апостолској столици и Цркви Светог Николе у Барију, иначе познати српској јавности, утицали на Тихомира Р. Ђорђевића да пре једног века и приношења за православне светиње у Палестини прогласи заједничким подвигом краљевске породице. ${ }^{27}$

Преписивач је највероватније био хиландарски проигуман Тимотеј Јовановић. Он је место о милосрдним делима краљице Јелене допунио интерполацијом о школи за девојке имајући пред очима као узор руску просвећену царицу Катарину Велику (1762-1796) која се заиста бавила оснивањем интерната за школовање девојчица и нахочади оба пола. Ове податке преписивач је преузео из књиге Захарија Орфелина Историја Петра Великог која је објављена у Венецији 1772. године, Тодић 2019, 3-14.

21 О мотиву братољубља у Јеленином житију види Бојовић 2015, 142-144.

22 Тодић $2018,40-43$.

23 Пејић 2014, 192-193.

24 Јеленина писма упућена папи Николи IV помињу се, између осталог, у његовом писму барском архиепископу Михаилу од 11. јуна 1291. године у вези са обновом разрушеног и запустелог града Caпе, Theiner 1863, 111 (№ 152). Исти папа је краљици писао и три године раније, 10. августа 1288, тражећи од ње да се потруди око тога да њени синови краљеви Стефан и Урош приђу јединству Цркве, Theiner 1859, 359-360 (№ 580).

25 Theiner 1859, 375 (№ 606).

26 Поповић 2010, 68-69.

27 Ђорђевић 1925, 9. 


\section{Извори}

ЖКЈ (2017): Архиепископ Данило Други, Житије краљище Јелене, прир. Д. Дојчиновић, Манастир Градац.

Theiner, Augustin (1859): Vetera monumenta historica Hungariam sacram illustrantia, I, Romae.

Theiner, Augustin (1863): Vetera monumenta Slavorum meridionalium, I, Romae.

\section{Литература}

Бојовић, Драгиша (2015): Теологија љубави у „Житију краљище Јелене”, Јелена - краљица, монахиња, светитељка, ур. К. Митровић, Брвеник: Манастир Градац, 139-146.

Дојчиновић, Данијел (2015): Хагиографичност Житија краљице Јелене, Јелена краљица, монахиња, светитељка, ур. К. Митровић, Брвеник: Манастир Градац, 151-166.

Ђорђевић, Тихомир Р. (1925): Српске светиње у Палестини, Скопље.

Јовић, Растко (2015): Краљица Јелена: светителство Истока и Запада, Јелена - краљица, монахиња, светитељка, ур. К. Митровић, Брвеник: Манастир Градац, 171-182.

Јухас Георгиевска, Љиљана (2013): Житије краљице Јелене од архиепископа Данила Другог, Семинар српског језика, књижевности и културе. Предавања 2, Београд: Међународни славистички центар, 27-40.

Копривица, Марија (2015): „Држава” краљице Јелене, Јелена - краљица, монахиња, светитељка, ур. К. Митровић, Брвеник: Манастир Градац, 13-26.

McDaniel, Gordon (1982-1983): On Hungarian-Serbian Relations in the Thirteenth Century: John Angelos and Queen Jelena, Ungarn-Jahrbuck 12, 43-50.

Пејић, Светлана (2015): Краљиияа и монахиња Јелена и ирква Благовештења манастира Градац - иртище о даривањима, Јелена - краљица, монахиња, светитељка, ур. К. Митровић, Брвеник: Манастир Градац, 187-196.

Поповић, Мирослав (2010): Српска краљица Јелена између римокатоличанства и православља, Београд: ПБФ Институт за теолошка истраживања.

Поповић, Мирослав (2015): Нови осврт на датовање писма-заклетве краљице Јелене дубровачком архиепископу, кнезу и општини, Јелена - краљица, монахиња, светитељка, ур. К. Митровић, Брвеник: Манастир Градац, 53-60.

Тодић, Бранислав Н. (2018): Култ градачке ктиторке краљице и монахиње Јелене, Саопштења 50, 33-50.

Тодић, Бранислав (2019): О иколи за девојке на двору српске краљице Јелене, Прилози за књижевност, језик, историју и фолклор 85, 3-14.

Томин, Светлана (2014): Српска краљища Јелена: владарка и монахиња, Нови Сад: Платонеум.

Узелац, Александар (2021): Марија де Кајо, сестра краљице Јелене, Између Подунавља и Средоземља. Тематски зборник посвећен проф. др Синиши Мишићу поводом његовог 60. рођендана, Ниш: Центар за црквене студије; Пожаревац: Народни музеј, 187-206. 


\section{Katarina Mitrović}

\section{QUEEN HELEN AND MOUNT SINAI}

In one of his lectures given at the University of Belgrade in February 1925, Tihomir R. Đorđević pointed out that the Serbian Queen Helen, with her sons, kings Dragutin and Milutin, had richly bestowed the Monastery of Virgin Mary at Sinai. On the trail of this information, the author has embarked on consideration of the data given by archbishop Danilo II in his work Life of Queen Helen. He knew Queen Helen well and was in a position to acquire reliable information about her life and work. According to him, Queen Helen had kept an epistolary friendship with the Orthodox clergymen in Jerusalem, Sinai, Rait and Mount Athos, going on for years until her death. Her letters were confessional in tone, as she disclosed her sins to the spiritual fathers and asked them for advice, edification and consolation. She dispatched the letters through trustworthy monks in her service. Together with these letters, the monks would carry rich donations to Sinai, Jerusalem, Mount Athos and Egypt. It is obvious from further text in his work that the donations consisted of books, priestly robes, golden and silver vases and chalices for divine celebrations. Queen Helen probably gifted them with icons as well, just as she had done with the Church of St. Nicholas in Bari or the Apostle See. Archbishop Danilo II included deliberations about the relations of Queen Helen with the Eastern Orthodox priests into the segment of her Hagiography, where he collected motifs of philanthropy manifested by acts of mercy. This is the only so far available and reliable information about the relations of that Serbian medieval queen and Mount of Sinai. 